DOI: $10.15290 /$ bb.2017.09.32

\title{
Zdobycze białoruskiej emigrantologii
}

Zapisy: Belarusian Institute of Arts and Sciences („Запісы”: Беларускі Інстытут Навукі і Мастацтва), New York - Miensk 2016, nr 38, ss. 612

Recenzowany almanach stanowi kontynuacje periodycznej publikacji „Запiсы", która została zapoczątkowana w 1952 roku w Nowym Jorku przez Białoruski Instytut Nauki i Sztuki. Pierwszych sześć tomów ukazało się w latach 1952-1954 w Nowym Jorku, pięć kolejnych w latach 1962-1970 w Monachium. W latach 1974-1999 periodyk znów był wydawany w Nowym Jorku, a od roku 2002 stanowi wspólny projekt nowojorsko-miński.

Kolegium redakcyjne almanachu tworzą: Natalla Hardzijenka (redaktor naczelny), Lawon Jurewicz, Thomas E. Bird, Janka Zaprudnik, Witaut Kipiel, Hienadź Sahanowicz oraz Siarhiej Szupa.

Jak zaznaczają redaktorzy tomu we wstępie, tematem bieżącego numeru jest „Pamięć', która jest szczególnie ważna dla kultury emigracyjnej. Jest ona obecna w tekstach, obrazach, ideach, zabytkach. Teksty zebrane w tym almanachu łączy jedna idea - zachowania pamięci o Białorusinach na obczyźnie.

Tom otwiera obszerny artykuł Natalli Hardzijenki Cmentarz jak część memorialnej kultury eтigracji (Могілкі як частка мэмарыляьнай культуры эміграubil, s. 8-70), który stanowi opracowanie informacji zawartych w multimedialnych bazach zamieszczonych na płycie CD dołączonej do almanachu. Jest to owoc kilkudziesięciu lat pracy różnych osób zaangażowanych w zbieranie informacji o białoruskich mogiłach na Zachodzie.

Dla Natalli Hardzijenki cmentarz stanowi swoisty tekst kultury, miejsce znaczące dla tożsamości danej zbiorowości kulturowej, a także świadectwo ciągłości historycznej. Jest to miejsce przesycone mnóstwem elementów kultury, swoista przestrzeń pamięci, bez której trudno mówić o świadomości historycznej danego narodu. Autorka artykułu analizuje szereg elementów związanych z pomnikami cmentarnymi, w szczególności interesuje ją symbolika nagrobka oraz umieszczone na nim inskrypcje. Wszystkie te elementy, zdaniem Hardzijenki, pozwalają lepiej zrozumieć specyfikę życia białoruskiej społeczności emigracyjnej, podstawy i mechanizmy jej działalności, a także określić hierarchię wartości Białorusinów na emigracji. 
Fundamentem poczynionych analiz są białoruskie nagrobki znajdujące się w najbardziej znaczących białoruskich ośrodkach emigracyjnych: South River, Cleveland oraz East Brunswick w USA, Melbourne, Sydney oraz Perth w Australii, a także nekropolie brytyjskie w Londynie i Manchesterze. W innych krajach - Kanadzie, Francji, Niemczech trzeba było szukać pojedynczych grobów na ogromnych wielonarodowych cmentarzach, co nie było sprawą prostą. Interesujące, że teksty nagrobkowe, obok podstawowych informacji na temat miejsca narodzin i śmierci danej osoby, zawierają także często informacje określające jej status społeczny i rodzinny, a także wiersze białoruskich poetów, fragmenty znanych pieśni czy symbole narodowe (np. znak Pogoni). Nie brakuje także symboli religijnych (najczęściej umieszczany jest na nagrobku krzyż Eufrozyny Połockiej) oraz świeckich (bławatek, kłosy, białoruski ornament).

Artykuł Natalli Hardzijenki bez wątpienia wypełnia ogromną lukę w badaniach nad kulturą białoruskiej emigracji, mówi o tym wyjątkowym momencie, w którym przeszłość styka się z teraźniejszością. Wnikliwość i wieloaspektowość poczynionych analiz zagwarantowały autorce sukces naukowy. Warto wspomnieć, że artykuł ten został uznany za najlepszy artykuł naukowy w dziedzinie historii i otrzymał nagrodę VII Międzynarodowego Kongresu Badaczy Białorusi, jaki odbywał się w dniach 15-17 września w 2017 w Warszawie.

Zachowaniu pamięci o działaczach, ośrodkach oraz wydarzeniach, związanych z historią białoruskiej emigracji, sprzyja także kolejna część almanachu zatytułowana Epistolarne archiwum Janki Zaprudnika (Эпісталярны архіў Янкі Запрудніка), na który składają się teksty Radio (Радbiё, s. 71-137) oraz Białoruska Argentyna w listach i notatkach (Беларуская Аргентына ў лістах $i$ доnicax, s. 138-163). Analizując bogatą spuściznę epistolograficzną znanego białoruskiego historyka, politologa i działacza emigracyjnego Janki Zaprudnika, Lawon Jurewicz odsłania interesujące i nieznane karty bogatej historii białoruskiej redakcji radia „Swaboda” oraz hiszpańskiego radia w Madrycie. Na podstawie korespondencji Zaprudnika z Emilem Ciołowskim kreśli barwny obraz białoruskiego życia w Argentynie. Uwaga Jurewicza skierowana została nie tylko na możliwości edukacji białorutenistycznej w Argentynie, ale też na codzienne życie argentyńskich Białorusinów, ich życiowy status, zarobki, a także kontakty z ojczyzną.

Dopełnieniem tej części publikacji jest rubryka $Z$ historii BINiM-u (3 гicmopыi БIHiMy), w której opublikowane zostały przedruki protokołów Białoruskiego Instytutu Nauki i Sztuki (Пратаколь БIHiMy, s. 164-170). Protokoły te są ważne $\mathrm{z}$ dwóch powodów. Po pierwsze, zawarte są w nich informacje o działalności BINiMu, różnych inicjatywach, jakie podejmowali jego pracownicy. Po drugie, stanowią one świadectwo tego, że Instytut skupiał wokół siebie znanych białoruskich intelektualistów i twórców, a zatem jego historia to zarazem cząstka jednostkowych biografii. Interesujące, że protokoły te podpisane są ręką Natalli Arsienniewej, która pełniła funkcję sekretarki w Instytucie, a zatem w tym także kryje się ich wartość.

Kategoria pamięci stanowi także motyw przewodni kolejnych publikacji ze-

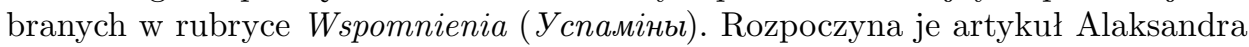
Paszkiewicza Ojciec Lew Haroszka i jego wspomnienia (A йцеu Леў Гарошка й ягоныля мемуары, s. 171-177) oraz wspomnienia ojca Lwa Haroszki Przez nawatnice 
i исіski. Wspomnienia z lat 1930-1944 (Праз навальнічь $i$ нягоды: Успаміны з гадоў 1930-1944, s. 178-367).

Jak przypomina Paszkiewicz, ten nie ukończony przez autora tekst miał złożoną drogę do publikacji, którą nareszcie można uznać za sfinalizowaną. Jego przygotowanie do druku rozpoczął bowiem ojciec Aleksander Nadson i Alaksandar Audziajuk.

Z osobą Lwa Haroszki związanych jest jeszcze kilka innych tekstów zamieszczonych w recenzowanym tomie. W Archiwaliach zamieszczone są listy literata Jurki Wićbicza do ojca Haroszki (Лiсть да айца Льва Гарошкі, s. 447-456), natomiast w artykule Lawona Jurewicza Pisarz Anatol Żmienia (Пісьменнік Анатоль ЖКменя, s. 432-439) ukazana została literacka działalność ojca Lwa Haroszki przez pryzmat jego zbioru prozy Kwiaty i ciernie żyсіа (Кветкі й черні жыџьия), na który złożyły się m.in. opowiadania Brat zbawiciel (Бpam cnaciuesb), Przemówito sumienie (Сумленьне загаварыла), Niespodzianka (Неспадзеўка), Sierota pod krzyżem (Cірата пад крыжам), Ludzie o czystym sumieniu (Людзі з чыстыьм сумленнем), Nerwy nie wytrzymaty (Нэрвы не вытрылмалі), Ludzka krew nigdy nie jest przelewana daremпiе (Людзкая кроў ніколі марна не гіне) oraz opowieść Nieznane drogi (Няведамьяя шляхі).

W rubryce Wydanie (Вьъданьне) Alaskandar Audziajuk opowiada o założonym przez ojca Haroszkę w Paryżu czasopismo „Bożym Szlakiem” („Божым Шляхам”). Pełna bibliografia tego czasopisma zamieszczona została w drugim dodatku CD do almanachu.

Interesująco przedstawia się także rubryka Publikacje (Публікацbii), w której omówione zostały najnowsze wydania poświęcone białoruskiej kulturze emigracyjnej. Maks Szczur na podstawie studiów nad archiwalnymi dokumentami opowiada о Lwie Klejnborcie (Клейнбарт думае пра Беларусь, s. 368-417), warszawscy historycy Jerzy Grzybowski i Marzena Grzybowska przedstawili materiały dotyczące próby zapoczątkowania działalności katolickiego duszpasterstwa białoruskiego w obozach DP w powojennych Niemczech (Да гісторьі беларускага дуипастырства рьлма-каталічкага веравьзнаньня ў лягерах DP на тэрыторыі Нямеччыныь (1945-1951), s. 418-431), natomiast Lawon Jurewicz ukazał różne strony i okoliczności konfliktu biskupa Czesława Sipowicza z działaczem społecznym Jazepem Paźniakiem (Audiatur et altera pars, s. 440-446).

Dalszą część almanachu zajmują Archiwalia (Архівалii), w których, obok wspomnianej wcześniej publikacji Lawona Jurewicza, umieszczony został artykuł Jerzego Grzybowskiego stanowiąc wynik archiwalnych poszukiwań dotyczących zagadnienia ruchu białoruskiego w międzywojennej Łotwie (3 гісторыi беларускага руху ў Латвіі у міжваенны й ваенны пэрыяды, s. 457-480).

Ważną kwestią poruszoną w almanachu jest działalność dokumentalna centrów emigrantologicznych. W rubryce Centrum gromadzenia $i$ badania dokumentalnej spuścizny białoruskiej eтigracji przy BDAMLM (Цэнтар камплектаваньня й вывучэньня дакумэнтальнай спадчыны беларускага замежжа пры БДАМЛМ) zаmieszczona została rozmowa Natalli Hardzijenki z dyrektor Białoruskiego Państwowego Archiwum-Muzeum Literatury i Sztuki Hanną Zapartyką na temat zbierania, gromadzenia i zachowania archiwów emigrantów (Архівь замежных беларусай: зьбіраньне, захаваньне, практыцныяя заўвагі, s. 481-495) oraz opis emigracyj- 
nych fundacji, których działalność w ostatnim czasie udało się opracować (Фондbl эміграчьйных дзеячаў у БДАМЛМ, s. 496-508).

Uwaga została także zwrócona na działalność drugiej ważnej instytucji powołanej na Białorusi - Centrum Badań Diaspory i Zagranicznego Białorusoznawstwa w Grodnie (Цэнтар дасьледаваньняў дыяспарай і замежнага беларусазнаўства ў Горадні). O ich genezie, planach opowiedzieli Zmicier Karau i Nastassia Dudźko w artykule Projekt „Zagraniczne białorusoznawstwo XVI - pocz. XXI w." i utworzenie nowego centrum badania tej problematyki (Праекm "3aмежнае беларусазнаўства XVI- пач. XXI cm." і стварэньне новага иэнтру дасьледаваньняў гэтай праблемь, s. 509-515).

Działalność czasopiśmienniczą białoruskich emigrantów przybliża publikacja Alaksandra Audziajuka Czasopismo „Bożym Szlakiem” i jego trzej redaktorzy ( 4 сопіс "Божым Шляхам" (1947-1980) і ягоныяя тры рэдактары, s. 516-543).

Redaktorzy tomu upamiętnili także ważne jubileusze: 100-lecie urodzin emigracyjnego poety Michasia Kawyla (Да 100-годзьдзя Міхася Кавыля, s. 544548 ) oraz 50. urodziny Lawona Jurewicza (Паўстагодзьдзя Лявона Юрэвіча, s. 549-552).

Nie zapomniano także o zmarłym niedawno, bo zaledwie w 2015 roku, ojcu Aleksandrze Nadsonie, o którym opowiedział Hienadź Sahanowicz w artykule O ojcu Alaksandrze Nadsonie jako historyku (Пра айца Аляксандра Надсана як гісторыка, s. 553-557) oraz o nagłym odejściu w 2016 roku językoznawcy Zmiciera Sauki, którego wspomniała Natalla Hardziejnka (Зьмічер Саўка (26.0\%.1965-09.04.2016) (замест нэкралёгу), s. 558-559).

Stałe rubryki almanachu $-Z$ ksiażkowej pótki (Кніжная nаліџа) і Kronika (Хроніка) zaznajamiaja z nowymi publikacjami związanymi z tematyką emigracji i wieloma ważnymi wydarzeniami w białoruskiej emigrantologii ( "Вiдыıмусы" Лявона Юрэвіча, s. 560-562; Дзьве кнігі, дзьве асобь -адна гісторьия, s. 563-566; Кніжны агляд, s. 567-590; Прэмія імя Аляксандра й Марыі Стагановічаў, s. 591-592; Новыя паступленьні дакумэнтаў замежных беларусаў у БДАМЛМ, s. 593-596; "Беларускае замежжа ў гісторыі й сучаснасьиі" на V Міжнародным Кангрэсе дасьледнікаў Беларусі ў Коўне, s. 597-598).

Końcową część almanachu stanowią podziękowania złożone Hannie Zapartyce przez pracowników Białoruskiego Instytutu Nauki i Sztuki (Удзячнасьць БIНIMy - Ганьне Запартыциь, s. 599), informacje o autorach artykułów zamieszczonych w tomie (Зьвесткі пра аўтараў, s. 600-603) oraz anglojęzyczne streszczenia poszczególnych publikacji (Summary, s. 604-608).

Prezentowany almanach stanowi bez wątpienia interesującą propozycję wydawniczą. Ukazuje on różne wymiary pamięci, podkreśla jej wage dla zachowania kulturowej ciągłości i tradycji, jej rolę w formowaniu się tożsamości osobowej i narodowej. Wielość tekstów zebranych w tomie, szeroki zakres problemowy i różne perspektywy badawcze dopełniają $\mathrm{w}$ istotnej mierze zdobycze białoruskiej emigrantologii i stanowią jednocześnie zachętę do pogłębiania wiedzy na temat wciąż jeszcze mało znanych aspektów życia Białorusinów poza granicami ojczyzny. 